\title{
Workers age 50 and over in the Brazilian labor market: is there ageism?
}

\section{Wilson Amorim, AndréLuiz Fischer and Fabiana Bitencourt Fevorini Faculdade de Economia Administracao e Contabilidade, Universidade de Sao Paulo, Sao Paulo, Brazil}

\begin{abstract}
Purpose - This paper deals with the insertion of workers aged 50 years or more in the Brazilian labor market. Considering this question, the purpose of this paper is to raise evidence about the existence of ageism - prejudice against that age range. The paper identifies the characteristics of participation by workers age 50 or older in Brazil's formal labor market. The paper also identifies whether and how the specific issues of these workers are handled in the individual employment contract, with the human resources management (HRM) policies and practices of a group of companies.

Design/methodology/approach - The study applied a quantitative approach in an analysis of the older population in the Brazilian labor market (Annual Social Information Report (RAIS) database and "MEPT" survey database - 2011/2016). The RAIS data are collected annually by the Ministério do Trabalho e Emprego - MTE, coming from all establishments with or without formal employees, whether statutory (public servants) or private organizations. MEPT survey is an annual study focused on quality of the organizational environment and HRM practices (organizations participate voluntarily). A qualitative approach was applied also in a document content analysis on information about HRM policies and practices based on MEPT companies' research evidence reports. Findings - There is evidence of ageism among private companies in Brazil with better HRM. These companies hire proportionally less old workers than the market and their HRM policies and practices scarcely handle with employees. The workers age 50 and over among the workers employed (private and mixed capital companies) have growing participation in the labor market. The profile of these workers is predominantly male, higher level education considering the market average, and working under longer lasting formal contracts comparing all workers combined. People involved in the individual hiring of workers from this age group do not even give this subject much attention.

Research limitations/implications - The specific objective of verifying if and how the specific issues that workers of 50 years and older are dealing; in the individual hiring for work, encountered limitations based on the restricted character of the data presented. In particular, the information related to the best companies (MEPT) is representative only of its own group and thus is restricted to the private sector. Although this cannot be generalized, they offer support for reflections on the subject.

Practical implications - This paper shows how companies with advanced HRM handle with older workers in their policies and practices.

Social implications - This work points out that that the aging of workers will be a problem to be discussed by the companies HRM in the future.

Originality/value - This paper identifies the need to study how companies will deal with the increasing number of older workers.
\end{abstract}

Keywords Ageing, Labour market

Paper type Research paper

\section{Introduction}

Brazil, long regarded as having a relatively young population, is quietly expanding the participation of older people in the labor market. In human resources management (HRM) in Brazil, themes such as generations X, Y and Millennials still predominate, with a focus on

(c) Wilson Amorim, AndréLuiz Fischer and Fabiana Bitencourt Fevorini. Published in Revista de Gestão. Published by Emerald Publishing Limited. This article is published under the Creative Commons Attribution (CC BY 4.0) licence. Anyone may reproduce, distribute, translate and create derivative works of this article (for both commercial and non-commercial purposes), subject to full attribution to the original publication and authors. The full terms of this licence may be seen at $\mathrm{http} / / /$ creativecommons.org/licences/by/4.0/legalcode

Brazilian labor market

Received 5 September 2018 Revised 24 December 2018 14 February 2019

Accepted 14 February 2019 (1) 
REGE

26,2

162

the young and their perceptions and desires about work. In contrast, the position and opinion of the older age groups within the labor market are scarcely known. The way that these workers are hired, either in collective bargaining (with unions) or individually by companies, is also unknown (Cordeiro, Freitag, Fischer, \& Albuquerque, 2013). However, population aging and the labor market are processes that are being increasingly studied in Brazil (Carvalho \& Wong, 2010). This paper deals with the inclusion of workers age 50 and over in the Brazilian labor market. The delimitation of this group as older workers is aligned with Parry and Harris (2011) and Weiss and Bass (2002).

Thus, we intend to answer herein the following research question:

$R Q 1$. Are workers age 50 and over facing ageism (discrimination against people on the basis of their age) in Brazilian companies?

Considering this question, the overall objective of the work is to bring up evidence about the existence of ageism (prejudice against people on the basis of their age). For this, a survey was conducted on private companies' requirements for workers, focusing on the profile of this workforce in terms of gender, education and time with the company from a longitudinal perspective. The main database relates to the formal labor market, based on the period of the Annual Social Information Report (RAIS) from 2011 to 2014. In a comparative way, data are also presented on requirements for workers by a group of companies that orient their HRM practices in order to be recognized as one of the best employers in the market. The database used is from the survey "Melhores Empresas para Você Trabalhar - MEPT" (Best Companies To Work For). This research annually compiles data from hundreds of companies operating in Brazil, regarding their HRM policies and practices, as well as the perceptions of their employees regarding the work environment. From this database, information on human resources management policies and practices of these companies, focusing on the group of older workers, will also be analyzed.

The paper is organized as follows. In addition to this introduction, there is a topic in which the aging of the labor market in the international and the Brazilian national spheres is conceptually and historically treated, as well as how this fact has attracted attention of public policy makers, companies and researchers. This topic presents the evolution of the participation by age group in the Brazilian labor market. The third item presents the methodology and characteristics of the data used. In the fourth section, we present the analysis of the data found, and in the fifth section, the final considerations.

\section{Ageing and the labor market}

Despite all the economic instabilities experienced in recent decades, it has become clear that technological advances on issues related to health and basic sanitation, among others, have enabled a continuous improvement in people's living conditions. One of the consequences of this advance is population aging, one of the most important contemporary phenomena.

This phenomenon affects the organization of societies and changes family dynamics, directly influencing people's lives as well. In the context of public policies, population aging affects sensitive areas such as social security, education and the labor market, posing difficult questions for governments and their respective voters. The challenge that countries must face is the process of demographic transition, which is characterized by the passage from a stage defined by national populations with high fertility and mortality, and a preponderance of younger populations, to their opposite, in which lower fertility and mortality significantly increase the higher proportion of the elderly (European Commission, 2011). In different situations, according to their economic and social development conditions, there are countries that have already gone through this process - e.g. the USA, Sweden, France and others, such as Brazil, Singapore, Colombia and China, in which this transition is happening in an accelerated way (World Bank, 2011; DIEESE, 2016). 
It is also observed that there is a delay in the arrival of young people in the labor market, which reduces the relative participation of this group among the total number of workers in this space of social and economic relations. At the same time, the proportion of older people in the labor market rises, which may contribute to causing the unemployment of younger people. These changes attract the attention of institutions. The OECD (2013) reports that due to several factors, such as higher education and health levels, along with policy reforms, aimed at incentives to continue working to an older age, older workers in many countries are postponing their retirement.

The International Labor Organization (ILO) and the World Bank are concerned about the existence of ageism in society. Ageism arises from social relations and attitudes adopted about inherent characteristics of an age group, stereotyping it negatively (Ghosheh, 2008). One consequence of ageism is age discrimination, which, in the case of older workers, assumes an association between aging and productive decline. From that point forward, the difficulties faced by older workers in maintaining jobs within companies, or even in their search for employment, are justified (ILO, 2011).

The international literature identifies age stereotypes more commonly associated with older workers: low productivity, resistance to change, lower ability to learn, shorter tenure, higher costs (Posthuma \& Campion, 2009). Such stereotypes are reflected in managers' negative attitudes toward the decision to hire or even retain older employees (Fasbender \& Wang, 2017).

The international literature reports three reasons for the low presence of companies with proactive practices regarding the retention of older workers: the persistence of negative stereotypes regarding this group of employees, age discrimination and the lack of knowledge of how to retain them in companies (Armstrong-Stassen, 2008).

The concern about age prejudice stimulates the proposition of public policies to fight such discrimination (ILO, 2011). The ILO developed Recommendation No. 162 (1980) specifically to address the employment and occupation of older workers. This Recommendation - similar to the Decent Work guidelines adopted by the entity in the late 1990s - stresses the importance for workers in the over 50 age group of having the right to equal opportunities, training/vocational development, access to job security and career development. Its strongest recommendation for this group of workers even states that, in the transition from work life to freedom of activity, retirement should be voluntary (ILO, 1980). Initiatives in this direction were also taken within the framework of the European Union, which influenced its member countries (Parry \& Tyson, 2009).

Although these policies may have little effect in times of severe recession (Neumark \& Button, 2014) - such as during the 2008/2009 crisis and since 2015 in Brazil - the importance of public policies regarding the inclusion of older workers in the labor market is undeniable.

In fact, the OECD has a specific recommendation for employers to adopt managerial practices and support public awareness campaigns to eliminate age discrimination. The OECD recommendation also suggests that employers and workers' representatives jointly identify mechanisms to facilitate the retention of older workers (OECD, 2015). These managerial practices and mechanisms - such as specific health concerns and professional qualification for new career choices after retirement - have become more important for companies in developed countries (Armstrong-Stassen, 2008).

The ILO and OECD guidelines respond to the ethical needs of society for changes regarding the inclusion of older workers in the labor market. On the other hand, they are also aligned with studies that attest to the relevance of adopting managerial policies that contemplate diversity even as a competitive advantage (Hunt, Prince, Dixon-Fyle, \& Yee, 2018). In developing countries with large populations and heterogeneous labor markets, these guidelines are also important given the short time remaining for the necessary changes in their social security systems, national cultures and managerial practices. 
REGE

26,2

164

\subsection{Ageing and the labor market in Brazil}

In the Brazilian case, the demographic transition takes place in an accelerated way and emphasizes the need for important decisions regarding social security (Jorgensen, Rocha, \& Fruttero, 2011). In Brazil, the public social security system gets its funding from the mandatory individual contributions of workers in formal occupations, throughout their working life, to constitute the national retirement fund. In retirement, the concept of solidarity prevails (those who are now employed support those who have reached retirement age), and a minimum of 30 years and 35 years of contribution is required, respectively, for women and men to retire (with a maximum limit equivalent to $\$ 1,500.00$ ) (Instituto Nacional de Seguridade Social, 2018). With the aging of the population, as in the case of various countries in the world, measures are being considered to reform the social security system, such as increasing the minimum contribution time or even establishing a higher minimum age for retirement, in order to achieve financial viability of the public social security fund.

Moreover, after the year 2000, the labor market was heating up with the reduction of unemployment rates and the increase in the average income of employed persons (EP), creating conditions close to full employment, which had rarely been observed in Brazil until then (Amorim \& Fischer, 2015).

Here we address aspects related to the evolution of the population in Brazil and its effects on the labor market, as well as aspects related to the individual and collective hiring of workers in the 50 and over age group, to contextualize their employment. Brazilian population data show that in just over 50 years the country experienced a significant change in its characteristics. The World Bank reports that the Brazilian demography has five important characteristics: Brazil is still relatively young, but; its demographic transition is faster than that of other Latin American countries; the fertility rate has declined significantly over recent decades and is already considered low in international terms; the mortality rate has also fallen, but not as fast as fertility; the age structure of the population has been changing significantly, and this structure potentially favors economic growth (World Bank, 2011).

In the fifth aspect, population projections show that until the mid-2020s Brazil will enjoy the so-called demographic bonus. In this period, the combination of the characteristics of the Brazilian demography points to a situation in which the reduction in the number of children, the reduction of mortality and the prolongation of the active life of the people result in a reduction in the number of dependents - children or elderly - per active worker in the labor market. In the experience of developed countries, with the reduction of the proportion of dependent people in relation to those who are working, it becomes possible to increase savings in family budgets, generating the necessary funds for productive investment in the country and thus enabling the accumulation of capital. The bonus materializes because the accumulation of capital in this period opens a window of opportunity for economic growth.

Within the Brazilian population dynamics, the fall in the dependency ratio should occur until the mid-2020s. From this point on, due to the higher proportion of elderly people in the society, the number of dependents will begin to grow and the so-called demographic bonus will disappear (IBGE, 2008).

The years of validity for the demographic bonus should be used to make major changes in Brazilian society, in order to face a reality in which the proportion of older people increases. More structured public policies become necessary to meet the population's specific demands in health, social assistance and leisure, among other aspects. From an economic perspective, debates at the national and international levels indicate that a central question will be how to facilitate the funding of social security for a population that, after working for three or four decades, will still face another two or three decades of inactive life.

From the individual point of view, smaller families will count on active workers, and/or retiree pensions, that will have to pay for expenses of two or more inactive generations 
(young and/or old) in the same household. At this point, it is possible to predict that the horizon of people's participation in the labor market will also change. Most likely, the prospect of employment or its pursuit will extend beyond what it is today. In fact, especially in relation to the labor market, and according to the following table, this is probably already happening.

Table I shows that between the years 2003 and 2015, the distribution of Persons of Working Age[1] in six Brazilian metropolitan regions showed growth in participation from the 50 and over age group, reaching 35.2 percent of the total in the last year of the series. Persons in the Workforce (PIW) and EP may be deemed as approximate measures for what would be the supply and demand for labor in these metropolitan regions. This table includes both formal and informal workers[2]. In both columns, there is a significant growth in the participation of the group of workers age 50 and over, reaching close to 25 percent of the total in both statistics. On the other hand, in the groups with people up to 24 years of age, the decrease in participation was also significant. During this period, the groups of PIW and $\mathrm{EP}$, with a higher educational level, increased from around 46 to approximately 66 percent (IBGE, 2016).

From 2003 to 2015, there was also a prolonged reduction of unemployment rates and a concomitant increase in the average income for heads of household (Ulyssea, 2014). These changes likely help to explain the reduction of youth participation in the labor market. Through this long-term cycle with the highest income seen by heads of household, their dependents are no longer pressured to seek an occupation early on. However, there is no doubt that population aging has also been largely responsible for changes in the age structure of the labor market in the regions studied.

\subsection{Ageing and HRM in Brazil}

Despite the signs for evidence of ageing in the labor market, what is noticeable is that in Brazil, the topic of generations is primarily addressed from the perspective of the young worker, both from the individual point of view, in their own careers, and from the expectations of the companies regarding them (Cordeiro et al., 2013). Deeper studies on the issue of youth have sought to relativize or even to reposition the presence of the so-called generations X and Y in the Brazilian organizational environment (Oliveira et al., 2012; Veloso, 2012; Lemos, 2012).

However, there were few studies that devote attention to the inclusion of workers age 50 and over in the labor market, and more generally, to the actual role of these people in society in the first decade of the 2000s (Goldani, 2010). Lima and Helal (2013) point out that among the top Brazilian journals, only five articles had been published in the five years prior to their work, and presence in the main national academic congresses is not much wider. In general, among the studies found, a qualitative approach prevails with frequent use of interviews as a data collection instrument of Lima and Helal (2013).

\begin{tabular}{lcccrrr}
\hline & \multicolumn{2}{c}{ Persons at working age } & \multicolumn{2}{c}{ Persons in the workforce } & \multicolumn{2}{c}{ Employed persons } \\
Age group (years) & 2003 & 2015 & 2003 & 2015 & 2003 & 2015 \\
\hline $10-14$ & 9.7 & 6.6 & 0.6 & 0.1 & 0.6 & 0.1 \\
$15-17$ & 6.4 & 5.0 & 2.9 & 1.4 & 2.1 & 1.0 \\
$18-24$ & 15.7 & 11.2 & 19.3 & 12.9 & 16.8 & 11.6 \\
$25-49$ & 44.9 & 41.7 & 61.7 & 60.7 & 63.8 & 61.4 \\
50 or more & 23.3 & 35.2 & 15.5 & 24.9 & 16.7 & 25.9 \\
Total & 100 & 100 & 100 & 100 & 100 & 100
\end{tabular}

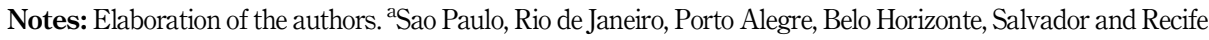

\section{Brazilian labor market}

165

$-$ 
REGE

26,2

166

Loth and Silveira (2014), in a study after Lima and Helal (2013), conducted interviews with older professionals and identified that they have stereotyped perceptions of themselves regarding their place at work, and in relational terms, also have stereotyped perceptions of others, especially younger people. Such perceptions signal the complexity of the condition of older individuals in the workplace. Among the more recent Brazilian authors focusing on the topic, Cepellos and Tonelli (2017) observed that, among Brazilian managers, a relatively positive view prevails regarding professionals over 50 years of age. However, they also found that such perceptions do not result in the adoption of specific HR practices for managing age in organizations. Moreover, companies will not be prepared for the current demographic change, not having specific policies or practices for this population group, thus incurring age prejudice.

Accordingly, the specific practices for attracting, hiring and retaining workers with this profile are rare. Thus there are no differentiated forms of individual contracting with a shorter workday, or even specific benefits such as health plans or adequate physical accessibility for older workers. In this sense, Pereira and Hanashiro $(2014,2015)$ point to the existence of age prejudice in relation to older workers, both in the selection process and in dismissal processes in companies operating in Brazil.

In a more recent work among Brazilian authors, Cepellos (2018) points out that the field of discussion regarding aging and the labor market is still scattered and lacking depth. The author points out that there are four main debates on the issue: the stereotypes of the mature professional and prejudice regarding age, the working conditions of the mature professional, the work of the mature professional for the organizations, and finally, the meaning of work for the mature professional.

Given that there is a prevalence of qualitative studies concerning the inclusion of older workers in organizations, and moreover, having data on the companies themselves as a source, in order to delve deeper into these issues, it would be interesting to have more information on the size and variation of the numbers relating to the employment of these people in the labor market. In a comparative way, data will be presented for the labor market as a whole and also for a specific sample of companies participating in the survey, Best Companies to Work For (MEPT), both for their older employees and for their HRM policies and practices. Such information will be dealt with in item 4 of this paper.

\section{Methodology}

The study applied quantitative and qualitative approaches. The analysis of the participation of the older population in the Brazilian labor market applied a quantitative approach in order to classify, rank, or measure variables by comparing groups and establishing comparisons (Vieira, 2009). Secondary data from the RAIS's databases at the Ministry of Labor and Employment (MTE [by its Portuguese acronym]) were used for this purpose. The RAIS data are collected annually by the MTE, coming from all establishments with or without formal employees, whether statutory (public servants) or private organizations. The collection of RAIS data may be considered a census of the organizations in Brazil (around 4.5m) and the information from the workers and their workplaces refer to December 31 of the year in question. This information represents the demand of the established organizations in the formal labor market in Brazil. This paper was prepared using the database available for 2015.

The data from the research "As Melhores Empresas para Você Trabalhar" (The Best Companies To Work For) (MEPT), carried out by the Programa de Gestão de Pessoas (People Management Program) at the Fundação Instituto de Administração (Institute of Administration Foundation) (PROGEP/FIA) were also used. The information obtained relates to the HRM policies and practices stated by the top 150 ranked companies in the MEPT survey. An annual study, it focuses on the quality of the organizational environment 
and the HRM practices in organizations that voluntarily participate in it. These are private capital organizations that employ 100 or more employees (in 2014, this minimum number was 200 employees). Organizations included in the MEPT database (as any other in Brazil) are also included in the larger RAIS database. However, the data used here for these companies were obtained using the MEPT research methodology as follows. The information about their organizational environment is the result of the responses from a sample of employees in each company, and those related to HRM are the responsibility of the management of each organization. The assumption is that the intent of these companies is to stand out in the labor market as good employers, both for their workplace environment and for their HRM. Thus, it is considered that these organizations could be taken as representative of HRM policies and practices above the average of other private organizations in Brazil. Information on HRM is recorded in the actual form from the research, and also in an evidence report sent by the companies, the source of the data analyzed in this paper (PROGEP/FIA, 2015). In this paper, we will present the age and educational profile of the workers responding to the survey from data available for the years 2011 to 2016 .

The study also has qualitative aspects. Qualitative research has an exploratory intent and is based on samples that provide insights and understanding based on the context of the problem (Malhotra, 2012). The qualitative research was, in this sense, documentary. It dealt with materials that had not yet received analytical treatment and were re-elaborated according to the study objectives (Gil, 2011). Content analysis was applied to these documents in order to get an objective and systematic description from the communications (Malhotra, 2012). In content analysis it is important to perform pre-analysis, exploration of the material, and finally, treatment of results in order to draw possible inferences and interpretations (Bardin, 2016). In this perspective, information on HRM policies and practices are obtained from a database derived from the MEPT, in companies' research evidence reports from the PROGEP/FIA files.

\section{Data analysis}

Results related to the RAIS and also to the MEPT - PROGEP/FIA database are presented in the following topics.

\subsection{Workers age 50 and over - RAIS - MTE}

In the following tables, it is possible to identify a set of characteristics related to the participation of workers age 50 and over in terms of formal occupation in the period 2011 to 2015 .

Table II shows data on the distribution of workers' contracts in the RAIS, by economic activity sector, in 2015, discriminating the age groups below 50 years of age and 50 years

\begin{tabular}{lcccrr}
\hline Sector economic activities (IBGE) & Less than 50 & 50 to 64 & 65 or more & Total & \\
\cline { 1 - 3 } Mining industry & 0.50 & 0.51 & 0.39 & 0.50 & \\
Transformation industry & 16.55 & 12.05 & 8.80 & 15.74 & \\
Industrial utility service & 0.82 & 1.48 & 1.48 & 0.93 & \\
Construction & 5.05 & 5.01 & 5.15 & 5.04 & \\
Commerce & 21.63 & 11.28 & 9,08 & 19.83 & Table II. \\
Service & 36.11 & 33.56 & 34.92 & 35.69 & Distribution of formal \\
Public administration & 16.32 & 32.52 & 36.55 & 19.14 & employment by sector \\
Farming, plant extraction, hunting and fishing & 3.03 & 3.58 & 3.64 & 3.12 & age group (years) \\
Total & 100 & 100 & 100 & 100 & according to economic \\
Workers & $39,826,006$ & $7,660,482$ & 574,102 & $48,060,590$ & activity sector \\
Source: RAIS.MTE & & & & & Brazil - 2015 (\%) \\
\cline { 1 - 3 } & & & & &
\end{tabular}


REGE

26,2

168

and over. It is noted that the three groups have a significant participation in the services sector in common - close to or slightly above one-third of the total. However, the groups for age 50 and over also have a significant participation of workers in the public sector - also around one-third. In proportional terms, it is practically double the participation of the younger groups. The group of workers under 50 has a proportionately larger share of workers in commerce and in manufacturing industries - 21.63 and 16.55 percent, respectively.

This paper's interest is focused on companies that belong to the private or even mixed capital sector, due to their greater sensitivity to the working conditions of the labor market. On the other hand, employment in the public sector in Brazil has, among its characteristics, greater permanence of employees in their jobs and, therefore, greater proportional participation by people included in advanced age groups. That said, in the following tables, only private or mixed capital data are analyzed.

According to Table III, initially we can see that the two age groups with the most significant positive variation in the period covered, in percentages, were those for workers age 50 and over. For the other groups, there was relative stability - groups from 30 to 49 years - or there was a decrease in participation - as in the groups between 18 and 29 years. The groups between 10 and 17 years of age are taken as residuals for the purposes of this study.

Despite the effects of the economic situation, with the country's low growth rates in the most recent period, on the formal employment represented by the RAIS data, the period covered follows a trend already identified for employment in the labor market of the metropolitan regions surveyed by the Brazilian Institute of Geography and Statistics (IBGE, 2016), for aging of the workforce. Moreover, the variations observed year by year in the older worker groups in the RAIS data are small, but the movement accumulated over the four years together may be considered structurally consistent. In other words, it follows the population movement of aging. This perception of the aging of those employed in the formal labor market is reinforced by the decline in the total number of workers, considering only private or mixed companies, between 2014 and 2015. In this period, given the Brazilian economic crisis, there was a decrease from 39.6 to $38.2 \mathrm{~m}$ ( 3.5 percent less), while the number of contracts with workers age 50 and over varied positively (1.8 percent), from 5.2 to $5.3 \mathrm{~m}$ in the same period (Table IV).

Table IV shows that the contingent of workers age 50 and over increased by 1,132,917 workers' contracts between 2011 and 2015. Furthermore it is noted that, with these workers as a whole, the participation of those of age 65 and over is increasing. In 2011, the share of workers age 65 and older, out of the total workforce (from 50 years of age onwards), was 5.3 percent, rising to approximately 6.5 percent in 2015 . In absolute terms, in the last year, the RAIS registered just over 344 thousand formal jobs in this age group.

Table III.

Distribution of formal employment $^{\mathrm{a}}$ by worker age group Brazil - 2011 to $2015(\%)$

\begin{tabular}{lccccc}
\hline Age group (years) & 2011 & 2012 & 2013 & 2014 & 2015 \\
\hline $10-14$ & 0.0 & 0.0 & 0.0 & 0.0 & 0.0 \\
$15-17$ & 1.3 & 1.4 & 1.4 & 1.3 & 1.1 \\
$18-24$ & 20.1 & 19.6 & 19.0 & 18.3 & 17.4 \\
$25-29$ & 18.5 & 18.0 & 17.6 & 17.3 & 16.8 \\
$30-39$ & 29.6 & 30.1 & 30.4 & 30.5 & 31.0 \\
$40-49$ & 19.0 & 19.1 & 19.2 & 19.4 & 19.8 \\
$50-64$ & 10.8 & 11.3 & 11.8 & 12.4 & 0.9 \\
65 or more & 0.6 & 0.7 & 0.7 & 0.8 & 100 \\
Total & 100 & 100 & 100 & 100 & $38,251,923$ \\
Workers & $36,682,705$ & $37,991,713$ & $39,150,252$ & $39,619,638$ &
\end{tabular}

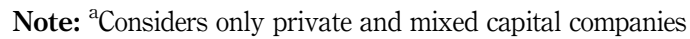
Source: RAIS.MTE 
Analysis of the Brazilian formal labor market by worker gender shows that over the last few years there has been a clearly increasing trend for the employment of women, either among younger workers (up to 49 years of age) or among the oldest (from 50 years of age onwards). However, as Table V shows, among the 50 and over age groups, the predominance of male workers is higher than that of all the RAIS workers under 50, considering private and mixed capital companies, between 2011 and 2015. Furthermore, in this period, the proportion of women in the formal labor market had a greater positive variation for women of age 50 and over (3.3 percent) than for women up to 49 years of age (2.3 percent).

Table VI shows that in proportional terms, workers age 50 and over are less educated, with 48.97 percent having up to an incomplete high school level in 2015. Comparing to workers up to 49 years of age, this percentage reached 29.3 percent in the same period. Younger workers are concentrated at the high school level, corresponding to more than half of this contingent (52.68 percent). This shows a tendency in the last few years, among young people, of expanded access to education, particularly high school (IBGE, 2016). This trend allows for projecting into the future - due to population and labor market evolution - that there will be workers from the older age groups that have more schooling.

One of the hallmarks of the Brazilian labor market is the high turnover of workers. The time spent in the last job can be taken as one of the indicators of this turnover. Table VII shows that younger workers spent less time in their last position compared to older workers (from 50 years onwards). In the total number of workers age 50 and over, those who remained between 2011 and 2015, and with more than ten years in their last contract, corresponded to more than $1 / 4$ in all the years analyzed. Whereas, in the total of those under 50 , in the same period, this percentage was around 6.0 percent. Among the younger ones, the tendency to move around more in the labor market is evidenced by the fact that among them, those who remained less than 12 months in their last job in 2015 reached 35.8 percent.

In summary, among the private and mixed capital establishments in Brazil, the group of workers age 50 and over found in the RAIS database has a growing participation in the labor market, a greater male predominance, higher education, and is employed with longer lasting and more formal contracts compared to all workers combined.

\subsection{MEPT-age profile of respondents}

After this general picture, in Tables VIII and IX we can observe the age and educational profile of workers responding to the MEPT survey. The respondents are employed in the 150 organizations with the highest ranking in the survey in terms of their workplace environment and the quality of their HRM.

Table VIII shows the profile of the respondent employees from the MEPT 150 best companies between the years 2011 and 2015. A necessary methodological consideration in relation to the table presented is that each year a different set of 150 companies are classified in the ranking. Also, the number of respondents varies from year to year in the above table (58,481 in 2014 and 51,341 in 2013). However, it is considered that this oscillation does not cause significant losses for this work, thus not jeopardizing the intended analysis.

\begin{tabular}{lccccc}
\hline Age Group (years) & 2011 & 2012 & 2013 & 2014 & 2015 \\
\hline 50 to 64 & 94.7 & 94.5 & 94.2 & 93.9 & 93.5 \\
65 or more & 5.3 & 5.5 & 5.8 & 6.1 & 6.5 \\
Total & 100 & 100 & 100 & 100 & 100 \\
Workers & $4,180,693$ & $4,531,896$ & $4,920,177$ & $5,218,454$ & $5,313,610$
\end{tabular}

Note: ${ }^{a}$ Considers only private and mixed capital companies Source: RAIS.MTE

\section{Brazilian labor market}

169 
REGE

26,2

170

Table V.

Distribution of formal employment $^{\mathrm{a}}$ by

selected age groups

and sex Brazil - 2011

to $2015(\%)$

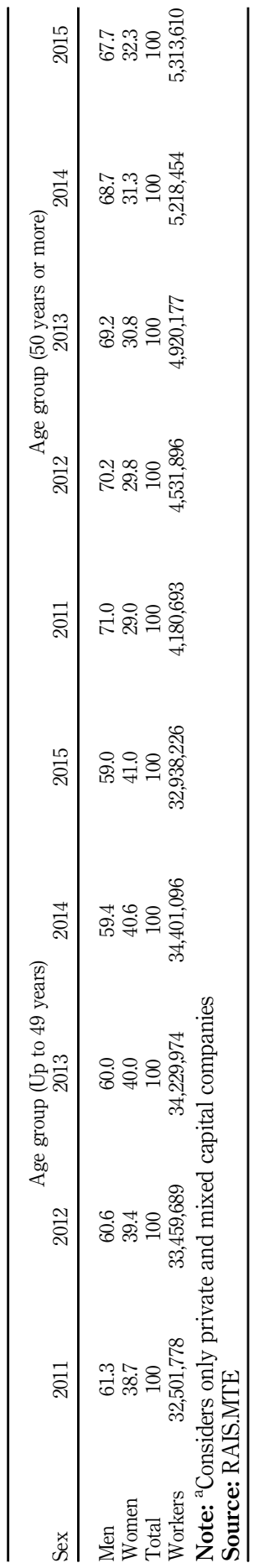


REGE

26,2

172

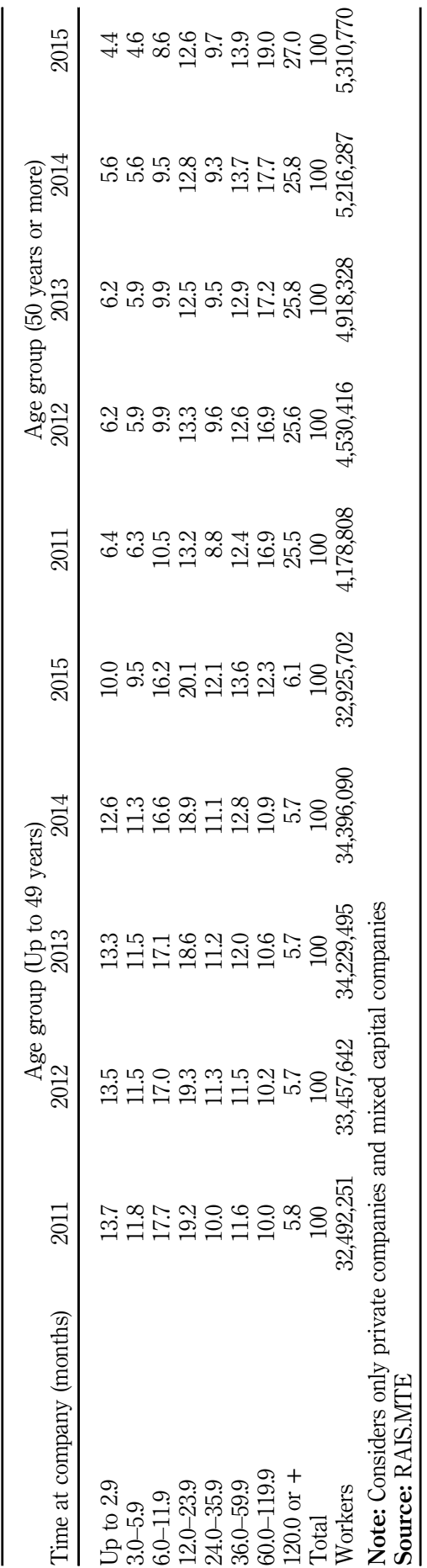

Table VII.

Distribution of formal employment workers by time at company group Brazil - 2011 to 2015 (months) (\%) 
However, although the group of companies is different from year to year, the participation of the age groups over the years surveyed in the MEPT is practically constant and is always different from that verified in the RAIS (Table II).

The participation of the MEPT respondents from the 50 and over groups corresponds to around 60 percent of what is shown in Table III relative to the RAIS in the years for which there are data available. Next, it is noted that the groups from 30 to 49 years also have systematically larger participation in the MEPT data compared to the RAIS data. It is also seen that, in the 25 to 29 year age group, the MEPT data are proportionally higher than the Brazilian labor market RAIS data. In summary, in the comparison of the MEPT and RAIS data, a predominance of younger workers is seen, and consequently, a lower participation of older workers.

Although it is possible to detect a slight trend for increased participation of older workers in the MEPT, it seems clear that there is a divergence of these companies in relation to the trend in the general population and, more specifically, in the formal labor market. In this sense, under the assumption that MEPT companies have more structured HR policies and practices than other companies, it is also possible to assume that they are better able to choose their employees from the labor market. The data presented for MEPT companies show a proportionately higher preference for younger workers, compared to RAIS data that represent all the companies that contract in the Brazilian labor market.

Table IX shows that among MEPT organizations there is also a higher proportion of employees with a higher level of education compared to RAIS data. Taking into account that in the RAIS there are proportionally more employees with more schooling, among young people, the greater preference of MEPT organizations for this age range can be explained.

The worker requirements preferences of these companies set older workers in the background. In other words, the practice of ageism by the MEPT companies becomes evident, at least in the decisions on hiring and retaining employees.

\begin{tabular}{lcccccr}
\hline Age Group (years) & 2011 & 2012 & 2013 & 2014 & 2015 & 2016 \\
\hline Less than 17 & 0.27 & 0.50 & 0.69 & 0.97 & 1.05 & 0.62 \\
$18-24$ & 15.61 & 15.12 & 14.15 & 15.33 & 14.12 & 13.95 \\
$25-29$ & 23.01 & 22.16 & 21.85 & 21.31 & 20.78 & 20.66 \\
$30-39$ & 35.78 & 36.56 & 37.23 & 37.15 & 38.19 & 38.32 \\
$40-49$ & 18.43 & 18.41 & 18.50 & 17.83 & 17.96 & 18.44 \\
$50-64$ & 6.71 & 7.07 & 7.36 & 7.24 & 7.71 & 7.80 \\
65 or more & 0.20 & 0.18 & 0.22 & 0.16 & 0.19 & 0.21 \\
Total & 100 & 100 & 100 & 100 & 100 & 100 \\
Workers & 52,167 & 53,803 & 51,341 & 58,481 & 58,457 & 61,441
\end{tabular}

Table VIII. MEPT companies (best 150) age groups of the respondents $(\%)$

Source: MEPT - PROGEP/FIA

\begin{tabular}{|c|c|c|c|c|c|c|}
\hline Schooling & 2011 & 2012 & 2013 & 2014 & 2015 & 2016 \\
\hline Elementary (complete or not) & 4.43 & 4.32 & 5.46 & 5.17 & 5.23 & 6.30 \\
\hline High School (complete or not) & 35.74 & 36.37 & 36.53 & 33.77 & 32.63 & 38.90 \\
\hline College (complete or not) & 41.69 & 40.35 & 38.74 & 41.62 & 41.67 & 40.20 \\
\hline Advanced degrees & 18.14 & 18.96 & 19.26 & 19.44 & 20.47 & 14.60 \\
\hline Total & 100.00 & 100.00 & 100.00 & 100.00 & 100.00 & 100.00 \\
\hline Workers & 52,167 & 53,803 & 51,341 & 58,481 & 58,457 & 61,441 \\
\hline
\end{tabular}

Source: MEPT - PROGEP/FIA 
REGE

26,2

174

\subsection{HR policies and practices for workers age 50 and older}

Table X presents the information on how these organizations treat their internal labor market, focusing on older workers. This table contains data on the policies and practices of these organizations in relation to their older employees. This table was developed from the previous reading and analysis of the evidence reports from the 150 MEPT companies in 2015, and grouping them according the common characteristics of their policies and practices.

In general, six different groups of organizations were found. They range from those that do not mention any concern with the generational issue, to those that state specific policies for older employees.

The first and largest group of organizations - 37.3 percent - did not mention any reference to the theme of "generations" and therefore did not address the situation of workers of age 50 and over. A second group of organizations regards the generation question by simply justifying that they do not adopt any program focused on employee preparation for retirement because of the predominance of young employees on their staff -16.6 percent of the organizations. A clue to understanding this fact might be found in the proportion of organizations that indicated not being worried about older workers. This group of 25 organizations, in fact, reinforces the perception that the organization's strategic choices in their labor requirements is concentrated on younger workers, so there is no other practical reason to focus managerial attention on older workers.

A third group - 11.3 percent of the total - merely cites "generations" among HRM concerns but does not indicate any reasons in this regard. Moreover, a fourth group indicates being against ageism but does not identify any HR policy or practice for confronting it, nor whether they are against ageism regarding younger or older workers. A fifth group - 7.3 percent of the organizations - pointed out generic, indirect, or even specific approaches to workers age 50 and over in their stated HR policies and practices.

Finally, only five of the organizations -3.3 percent referred specifically to older workers. In these cases of more specific policies and practices, there are programs in this age group for retirement preparation, health care and also professional qualification for new career choices after retirement.

It is then shown that even among the companies with advanced HRM policies and practices, there are few organizations geared toward the group of older workers. If the existence of HR policies and practices is related to the strategic interest of organizations in hiring specific employee profiles, it is concluded that few MEPT organizations prioritize older workers. RAIS data showed that in Brazil there is a greater and growing proportion of workers with higher education levels among younger workers. This may explain this preference of organizations for these workers.

In any case, even considering that MEPT companies have proportionally fewer older workers, it is clear that they are also negatively affected by the policies and practices of these organizations.

Table X.

MEPT companies (best 150) HRM policies and practices declared for workers aged 50 or older - 2015

\begin{tabular}{lrr}
\hline Policies and practices & Companies & $\%$ \\
\hline Without any reference to employees age 50 and over & 56 & 37.3 \\
Predominance of young employees is one reason for not adopting a retirement preparation & & \\
program or other policy/practice for employees age 50 and over & 25 & 16.6 \\
They only cite the topic "generations" as a HRM concern & 17 & 11.3 \\
Organizations that simply state that they do not tolerate ageism & 40 & 26.6 \\
Generic or indirect approaches to employees age 50 and over & 11 & 7.3 \\
Specific for the public age 50 and over & 5 & 3.3 \\
Total & & 150 \\
Source: MEPT - PROGEP/FIA - Evidence Reports Elaboration of the authors & & \\
\end{tabular}


After a documental analysis, these quantitative findings are in line with what has been verified among international authors like Armstrong-Stassen (2008), Posthuma and Campion (2009) and Fasbender and Wang (2017), as well as Brazilian authors such as Cepellos and Tonelli (2017), Pereira and Hanashiro (2014, 2015) and Loth and Silveira (2014). These authors, based on the perception of employees and managers, note the existence of ageism in organizations in Brazil and little presence of specific policies and practices for older employees. It should be noted that it is surprising that these phenomena are visible precisely among companies that intend to stand out for the quality of their HRM policies and practices and work environment. However, it is also clear that there is an ageing process underway in the labor market that will create problems for organizations that insist on HRM practices that ignore older workers. This is because in the future they will be a rapidly growing part of the labor market.

\section{Final considerations}

After analyzing the data presented, the paper identifies the characteristics of the participation of workers age 50 and over in the formal labor market, based on the RAIS data for the period 2011 to 2015. One-third of these workers are in the public sector, one-third in services and one-third in other sectors. On the basis of workers employed in private and mixed capital companies, it was identified that the group of workers age 50 and over has a growing participation in the labor market. The profile of this worker is predominantly male, schooling above the market average and employment with formal contracts that are longer lasting compared to all workers as a whole.

The data show that Brazil is following, in rapid steps, the same course as developed countries with regard to the ageing of its population (World Bank, 2011; Jorgensen et al., 2011). Institutionally, this ageing is behind the intense debate about the financing of social security in Brazil. The labor market is also related to this issue, first, because it is where a good portion of social security funding originates. Furthermore, as a reflection of demographics, in recent years, there are already proportionately more workers over 50 working, a significant contingent that will grow even more in the coming years.

The study verified if and how the specific issues of workers age 50 and older are dealt with in the individual hiring for work, but encountered limitations based on the limited nature of the data presented. In particular, the information related to the MEPT companies is representative only of its own group and thus is limited to the private sector. Although this cannot be generalized, it offers support for reflections on the subject.

What was noticed from the data presented is that the actors involved in the individual hiring of workers from this age group do not even give this subject much attention. The growth of the older population in the organizations raises a series of aspects yet barely dealt with by the organizations. These workers have less schooling, but this will increase over time. They stay or have been employed for a longer time and require adaptation of workplace environments, ways of hiring workers and the workday itself, more specific indirect benefit programs, such as health plans (with special concerns regarding older workers), for example, among others.

From this point of view, the strategic bias for the prioritization of younger workers by the most modern companies, in terms of HRM, explains, on the one hand, why there are few organizations with practices aimed at older workers. However, on the other hand, this same bias makes it difficult to deny the existence of ageism and, from there, some age prejudice in these organizations.

The international academic production indicates the low presence of companies with proactive practices for the retention of older workers (Armstrong-Stassen, 2008) and, by the way, far from the ILO, OECD, or World Bank recommendations. The paper's findings seem aligned with these authors. More than this, it is amazing that MEPT companies - organizations 
REGE

26,2

that want to stand out for their HRM policies and practices - show evidence of ageism. At this point, it can be stated that this paper provides an answer regarding the research question proposed. Expansion of the research related to the companies, for more details on the profile of the older workers in these organizations, would be interesting.

By the way, from the evolution of the demographic picture, and even of the labor market, there are other important questions. If the demographics and the labor market grow old and companies insist on the strategic and practical priority in hiring young people, it is reasonable to project shortages of this workforce in the near future. And scarcity in the markets means a rising cost of hiring. Have organizations already noticed this?

Apparently, most of them have not. It is worth reflecting on the functioning of the labor market and the forms of employment in countries that experience an aging process in their population, such as Brazil. This is because, although aging is an inexorable process, the scarcity of HRM policies and practices aimed at older workers indicates that organizations do not operate with a focus on the medium and long term. Thus the insistence on hiring younger workers will at some point stumble into the shortage of this workforce, and then the time for older workers will come.

Among the most developed societies, the experience of aging has raised concerns of various sorts. At the highest institutional level there are questions about how to make social security funding feasible by extending personal and professional life. In the context of social and labor relations, the need also emerges to combat forms of prejudice and discrimination against older workers who will necessarily have broader participation in Brazilian labor markets. The ILO and OECD recommendations about aging and better working conditions for older workers reflect these concerns.

Monitoring how organizations' HRM will treat older workers is therefore valuable in ensuring better active inclusion in society. The range of HRM policies and practices shown in Table X could be useful in this task. The data presented there reveal that organizations already discuss the issue of generations, by placing a focus on the generational labels $\mathrm{Y}$ and Millennials, in a rather common way in professional publications and consultancies in general. In these cases, attention to the presence of young people is also justified by the need for diversity in a general sense, and the coexistence of the various generations within organizations. However, judging by the data obtained on practices within organizations, these still exist on a very preliminary basis. In the specific case of older workers, they are almost non-existent.

In summary, in Brazil, there is an inevitable process under way in which it is already known that, in the middle of the next decade, the demographic bonuses period will come to an end. Henceforth, there will be a critical period from the generational point of view, with the proportional increase of older people being sustained by the younger ones. In similar countries, the same occurs or will occur. The combined effect of these trends already accelerates the participation of older workers in the labor market. These workers will have more and more longevity and, in the future, with a higher level of education, an already foreseeable profile that is different from that historically verified.

When will those who take care of hiring for jobs at companies wake up to this?

\section{Notes}

1. Group of Persons 10 years or older that totals around $44.9 \mathrm{~m}$ people in these six metropolitan regions.

2. In Brazil, between 8 and 10 percent of the employed are informal workers (who do not work with income tax and social security charges being withheld) (IBGE, 2016). 


\section{References}

Amorim, W. A. C., \& Fischer, A. L. (2015). Relações de Trabalho, Administração de Recursos Humanos e Ambiente Econômico e Social no Brasil: período 1990-2010. In Amorim, W. A. C. (Ed.), Negociações coletivas no Brasil: 50 anos de aprendizado (pp. 127-148). São Paulo: Atlas.

Armstrong-Stassen, M. (2008). Human resource practices for mature workers - and why aren't employers using them? Asia Pacific Journal of Human Resources, 46(3), 334-352, Available from: https://doi.org/10.1177/1038411108091755

Bardin, L. (2016). Análise de conteúdo. Edições, São Paulo, 70.

Carvalho, J. A. M., \& Wong, L. R. R. (2010). O novo padrão demográfico brasileiro: oportunidades e desafios para a sociedade, incluindo a academia. CAPES - coordenação de aperfeiçoamento de pessoal de nível superior, plano nacional de pós graduação 2011-2020 (pp. 153-174). Cedeplar/UFMG, Belo Horizonte.

Cepellos, V. M. (2018). Envelhecimento nas organizações: os grandes debates sobre o tema nos estudos de administração de empresas. Teoria e Prática em Administração, 8(1), 138-159. Available from: https://doi.org/10.21714/2018_v8i137614

Cepellos, V. M., \& Tonelli, M. J. (2017). Envelhecimento nas organizações: percepções e práticas de RH no Brasil. Revista Alcance, 24(1), 4-21. Available from: https://siaiap32. univali.br/seer/index.php/ra/article/view/9929/pdf_1

Cordeiro, H. T. D., Freitag, B. B., Fischer, A. L., \& Albuquerque, L. G. (2013). A questão das gerações no campo da gestão de pessoas: tema emergente? Revista de Carreiras e Pessoas São Paulo, $3(2), 2-18$.

DIEESE (2016). Os impactos das mudanças demográficas na seguridade social. Nota Técnica No. 160, julho, DIEESE, São Paulo.

European Commission (2011). Active ageing and solidarity between generations - a statistical portrait of the European union 2012. Publications Office of the European Union, Luxembourg, 141.

Fasbender, U., \& Wang, M. (2017). Negative attitudes toward older workers and hiring decisions: testing the moderating role of decision makers' core self-evaluations. Frontiers in Psychology, 7, 2057. doi: 10.3389/fpsyg.2016.02057

Ghosheh, N. (2008). Age discrimination and older workers: theory and legislation in comparative context. Conditions of Work and Employment Series, 20, 1-51. Available from: http://www.ilo.org/wcmsp5/groups/public/—ed_protect/—protrav/—travail/documents/ publication/wcms_travail_pub_19.pdf

Gil, A. C. (2011). Métodos e técnicas de pesquisa social. Atlas, São Paulo.

Goldani, A. M. (2010). Desafios do "Preconceito Etário" no Brasil. Educação \& Sociedade, 31(111), 411-434. Available from: www.scielo.br/pdf/es/v31n111/v31n111a07.pdf

Hunt, S., Prince, S., Dixon-Fyle, S., \& Yee, L. (2018). Delivering through diversity. Available from: www. mckinsey.com/business-functions/organization/our-insights/delivering-through-diversity

IBGE (2008). Projeção da população no Brasil por sexo e idade - 1980-1950. Available from: www.ibge.gov.br/estatisticas-novoportal/sociais/populacao/9109-projecao-da-populacao. $\mathrm{html} ?=\& \mathrm{t}=$ downloads

IBGE (2016). Pesquisa mensal de emprego: principais destaques da evolução do mercado de trabalho nas regiões metropolitanas abrangidas pela pesquisa: recife, Salvador, Belo Horizonte, Rio de Janeiro, São Paulo e Porto Alegre (2003-2015). Indicadores do IBGE.

ILO (1980). Older workers recommendation, 1980 (no. 162). Recuperado de, Available from: www.ilo. org/dyn/normlex/en/f?p=NORMLEXPUB:12100:0::NO::P12100_ILO_CODE:R162

ILO (2011). Age discrimination: Older than 50, so what? World of Work Magazine, 72, Available from: www.ilo.org/global/publications/magazines-and-journals/world-of-work-magazine/articles/ WCMS_165356/lang-en/index.htm 
REGE 26,2

Instituto Nacional de Seguridade Social (2018). Aposentadoria por tempo de contribuição. Available from: www.inss.gov.br/beneficios/aposentadoria-por-tempo-de-contribuicao/

Jorgensen, O. H., Rocha, R., \& Fruttero, A. (2011). Growing Older in an Older Brazil: implications of Population Aging on Growth, Poverty, Public Finance, and Service Delivery. Directions in Development, Available from: https:/openknowledge.worldbank.org/handle/10 986/2351

Lemos, A. H. C. (2012). Juventude, gerações e trabalho: ampliando o debate. Organizações \& Sociedade, 19(63), 739-743. Available from: https://dx.doi.org/10.1590/S1984-92302012000400010

Lima, T. B., \& Helal, D. H. (2013). Trabalho na terceira idade: uma revisão sistemática da literatura brasileira entre 2008 e 2012. Gestão e Sociedade, 7(18), 369-394. Available from: https://doi.org/ 10.21171/ges.v7i18.1914

Loth, G. B., \& Silveira, N. (2014). Etarismo nas organizações: um estudo dos estereótipos em trabalhadores envelhecentes. Revista de Ciências da Administração, 16(39), 65-82. Available from: https://doi.org/10. 5007/2175-8077.2014v16n39p65

Malhotra, N. K. (2012). Pesquisa de marketing: uma pesquisa aplicada, Bookman, Porto Alegre.

Neumark, D., \& Button, P. (2014). Did age discrimination protections help older workers weather the great recession? Journal of Policy Analysis and Management, 33(3), 566-601. doi: 10.1002/pam.21762

OECD (2013). OECD employment outlook 2013. OECD Publishing, Paris, Available from: https://doi. org/10.1787/empl_outlook-2013-en

OECD (2015). Recommendation of the council on ageing and employment policies. OECD/LEGAL/0419. Available from: https://legalinstruments.oecd.org/public/doc/333/333.en.pdf

Oliveira, S. R., Piccinini, V. C., \& Bittencourt, B. M. (2012). Juventudes, gerações e trabalho: é possível falar em geração Y no Brasil? Organização \& Sociedade, 19(62), 551-558. Available from: https:// dx.doi.org/10.1590/S1984-92302012000300010

Parry, E., \& Harris, L. (2011). The employment relations challenges of an ageing workforce. Acas Future of Workplace Relations discussion paper series, Available from: http://m.acas.org.uk/media/pdf/e/p/The_Employment_Relations_Challenges_of_an_Ageing_ Workforce.pdf

Parry, E., \& Tyson, S. (2009). Organizational reactions to UK age discrimination legislation. Employee Relations, 31(5), 471-488. Available from: https://doi.org/10.1108/01425450910979239

Pereira, M. F. M. W. M., \& Hanashiro, D. M. (2014). Etarismo em seleção: a dura realidade para quem tem mais de 45 anos no Brasil. XXXVIII EnANPAD, ANPAD, Rio de Janeiro, Available from: www.anpad.org.br/admin/pdf/2014_EnANPAD_EOR1794.pdf

Pereira, M. F. M. W. M., \& Hanashiro, D.M. (2015). Demissão de gestores mais velhos: reestruturação ou etarismo? V ENGPR, ANPAD, Salvador.

Posthuma, R. A., \& Campion, M. A. (2009). Age stereotypes in the workplace: common stereotypes, moderators, and future research directionst. Journal of Management, 35(1), 158-188. Available from: https://doi.org/10.1177/0149206308318617

PROGEP/FIA (2015) Melhores empresas para você trabalhar - Laudo Técnico, PROGEP/FIA, São Paulo.

Ulyssea, G. (2014). Panorama do mercado de trabalho brasileiro: uma análise de temas recentes. In Bonelli, R. (Ed.), Panorama do mercado de trabalho no Brasil, Editora FGV, (pp. 75-96). Rio de Janeiro.

Veloso, E. F. R. (2012). É possível negar a existência da geração Y no Brasil? Organização \& Sociedade, 19(62), 745-747. Available from: https://dx.doi.org/10.1590/S1984-92302012 000400011

Vieira, S. (2009). Como elaborar questionários. Atlas, São Paulo.

Weiss, R., \& Bass, S. (2002). Introduction. In Weiss, R. S., \& Bass, S. A. (Eds), Challenges of the third age: meaning and purpose in later life, Oxford University Press, Oxford, 3-13. 
World Bank (2011). Envelhecendo em um Brasil mais velho: implicações do envelhecimento populacional para o crescimento econômico, a redução da pobreza, as finanças públicas e a prestação de serviços, World Bank, Washington, DC, Available from: http://siteresources.worldbank.org/ BRAZILINPOREXTN/Resources/3817166-1302102548192/Envelhecendo_Brasil_Sumario_Ex ecutivo.pdf

\section{Further reading}

Brasil - MTE (2014). Características do emprego formal segundo a relação anual de informações sociais, Brasil - MTE, Brasília.

\section{Corresponding author}

Wilson Amorim can be contacted at: wamorim@usp.br

Associate Editor: Adriana Marotti de Mello

For instructions on how to order reprints of this article, please visit our website: 